\title{
Development of $\mathrm{O} / \mathrm{W}$ emulsions containing Euterpe oleracea extract and evaluation of photoprotective efficacy
}

\author{
Cláudia Cecilio Daher ${ }^{1,2}$, Ipojucan Silva Fontes ${ }^{2}$, Rayllan de Oliveira Rodrigues², \\ Gabriel Azevedo de Brito Damasceno², Daiane dos Santos Soares², \\ Cícero Flávio Soares Aragão ${ }^{3}$, Ana Paula Barreto Gomes ${ }^{3}$, Márcio Ferrari2,"*
}

\author{
${ }^{1}$ Faculty of Pharmacy, Potiguar University, Natal, RN, Brazil, ${ }^{2}$ Laboratory of Research and \\ Development of Cosmetic Products, ${ }^{3}$ Laboratory of Drug Quality Control, Faculty of Pharmacy, \\ Federal University of Rio Grande do Norte, Natal, RN, Brazil
}

\begin{abstract}
Euterpe oleracea Mart. is a palm tree popularly known as açai, which is primarily found in northern Brazil. The açai's fruits contain anthocyanins, a class of polyphenols to which antioxidant properties have been attributed. The aim of this work was to develop $\mathrm{O} / \mathrm{W}$ sunscreens emulsions containing açai glycolic extract (AGE) and to evaluate both their physical stability and photoprotective efficacy. Emulsions containing AGE and sunscreens were formulated using different types and concentrations of polymeric surfactant (acrylates/C 10-30 alkyl acrylate crosspolymer and sodium polyacrylate). The influence of two rheology modifiers (polyacrylamide (and) C13-14/isoparaffin (and) Laureth-7 and Carbomer) on the stability was also investigated. Physical stability was evaluated by preliminary and accelerated studies. Emulsions with $1.0 \%$ sodium polyacrylate were stable and exhibited non-newtonian pseudoplastic behavior and thixotropy. Photoprotective efficacy was evaluated by in vivo Sun Protection Factor (SPF) and determination of Protection Factor of UVA (PF-UVA). When AGE was added to the sunscreen emulsion, no significant increase in the in vivo SPF value was observed. The emulsion containing AGE showed PF-UVA $=14.97,1.69$ of the SPF/PF-UVA ratio and a critical wavelength value of $378 \mathrm{~nm}$, and may therefore be considered a sunscreen with UVA and UVB protection.
\end{abstract}

Uniterms: O/W emulsion/development. Euterpe oleracea/pharmacognosy. Euterpe oleracea/glycolic extract/photoprotective efficacy. Sunscreens/development. Sun Protection Factor.

Euterpe oleracea Mart. é uma palmeira popularmente conhecida como açaí, encontrada no norte do Brasil. O fruto do açaí apresenta em sua composição antocianinas, uma classe de polifenóis à qual é atribuída propriedade antioxidante. Os objetivos desse trabalho foram desenvolver emulsões fotoprotetoras $\mathrm{O} / \mathrm{A}$ contendo extrato glicólico de açaí (AGE), avaliar a estabilidade física e avaliar a eficácia fotoprotetora. Emulsões contendo AGE e filtros solares foram formuladas utilizando diferentes tipos e concentrações de tensoativo polimérico (acrilates/C 10-30 alquil acrilato polímero cruzado e polilacrilato sódico). A influência de dois modificadores reológicos (poliacrilamida (e) C13-14/isoparafina (e) Laureth-7 e Carbomer) na estabilidade foi avaliada. A estabilidade física das emulsões foi avaliada por meio de estudos de estabilidade preliminar e acelerada. Emulsões com 1,0\% poliacrilato sódico foram estáveis, exibiram comportamento não-newtoniano pseudoplástico e tixotrópico. A eficácia fotoprotetora foi avaliada pelo teste in vivo de Fator de Proteção Solar (FPS) e pela determinação do Fator de Proteção UVA (FP-UVA). Quando adicionado o AGE na emulsão contendo filtros solares, não se observou aumento significativo no valor do FPS. A emulsão contendo o AGE apresentou FP-UVA=14,97, a razão FPS/ FP-UVA $=1,69$ e o comprimento de onda crítico igual a $378 \mathrm{~nm}$, podendo ser considerado um protetor solar com proteção UVA e UVB.

Unitermos: Emulsão O/A/desenvolvimento. Euterpe oleracea/farmacognosia. Euterpe oleracea/extrato glicólico/eficácia fotoprotetora. Protetores Solares/desenvolvimento. Fator de Proteção Solar.

\footnotetext{
*Correspondence: M. Ferrari. Laboratório de Pesquisa e Desenvolvimento de Produtos Cosméticos, Universidade Federal do Rio Grande do Norte. Rua Gustavo Cordeiro de Farias, s/n - Petrópolis, 59012-570 - Natal - Rio Grande do Norte, Brasil. E-mail: ferrarimarcio@uol.com.br
} 


\section{INTRODUCTION}

In recent years, the incidence of ultraviolet radiationrelated diseases and disorders has grown, particularly in the form of skin cancers. According to estimates by the National Cancer Institute, for Brazil, there will be 182,000 cases of non-melanoma skin cancer and 5,890 new cases of melanoma in 2014 (INCA, 2014). Ultraviolet light is the most important carcinogen for the genesis of skin cancers (El Ghissassi et al., 2009) and excessive sunlight exposure, has been implicated as the main environmental agent responsible for skin cancer (Gandini et al., 2005).

A valuable tool for attenuating the deleterious effects of UV radiation (UVR) is photoprotection. Methods of photoprotection include actions aimed at education of population, change in habits, sun avoidance, seeking shade, use of protective clothing and correct use of sunscreens (Balakrishnan, Narayanaswamy, 2011; Lohézic-Le Dévéhat et al., 2013). Sunscreen use is the most common photoprotection alternative used by the population, and so these products should offer improved protection with broad-spectrum, UVA and UVB protection (Lohézic-Le Dévéhat et al., 2013).

The long-term effects of UV radiation include photoaging, immunosuppression, and photocarcinogenesis. UVA causes DNA damage via an oxidative process increasing the level of reactive oxygen species accompanied by cell membrane lipid peroxidation eventuating in cutaneous inflammation (Kullavanijaya, Lim, 2005).

Natural agents, with antioxidant potential and the ability to exert inhibitory effects on diverse cellular and molecular events are gaining considerable attention for the prevention of UV-induced skin damage (Afaq, Mukhtar, 2006; Afaq, 2011). Some substances naturally occurring in vegetal extracts are capable of absorbing ultraviolet radiation via chromophoric molecules associated with antioxidant activity (Sousa et al., 2007).

Polyphenolic compounds, such as flavonoids and anthocyanins are compounds that have antioxidant activity (Cliff, King, Schlosser, 2007).

Vegetal extracts containing flavonoids (e.g., Achillea millefolium, Hamamelis virginiana, Matricaria chamomilla, Mentha piperita and Salvia officinalis), reported in previous studies, were shown to be capable of absorbing ultraviolet radiation (Bobin, Raymond, Martini, 1994; Souza et al., 2005).

Green tea, Hamamelis virginiana, Matricaria recutita, Aesculus Hippocastanum, Rhamnus purshiana and Cinnamomum zeylanicum, and aromatic compounds isolated from lichens are examples of natural substances that have been evaluated for their sunscreen properties
(Ramos et al., 1996; Katiyar et al., 2001; Rancan et al., 2002; Bianchi, Marchetti, Scalia, 2011).

Açaí (Euterpe oleracea Mart.) is a palm native to the Amazon. Its fruits are of economic importance in the Brazilian state of Pará and contain in addition to essential nutrients, anthocyanins, a class of polyphenols to which antioxidant properties have been attributed (Kuskoski et al., 2006; Kang et al., 2011; Gordon et al., 2012; Inácio et al., 2013). Anthocyanins are the predominant polyphenols and account for more than $90 \%$ of açai's total polyphenolic contents (Pacheco-Palencia et al., 2009). However, anthocyanins may also serve as antioxidants and play a photoprotective role by directly eliminating reactive oxygen species during photoxidative stress (Zhang et al., 2010). Schauss et al. (2006) demonstrated the antioxidant capacity of açai pulp against superoxide anions and peroxyl radicals, exhibiting enhanced capacity, compared to any other fruit previously reported in the literature.

In a review article, Afaq and Mukhtar (2006) suggested that the use of plants with antioxidant activity (Punica granatum, Camellia sinensis) or isolated compounds (resveratrol and genistein) in combination with UV filters might be an effective approach for reducing free radicals generated by UV radiation.

Because of these properties, natural agents are gaining popularity in skin care products. The use of natural agents with antioxidant activities in sunscreen products represent an approach for preventing UV-damage (Afaq, 2011).

Sunscreen products have been formulated mainly as emulsions. However, emulsions are thermodynamically unstable systems and in technological development, the aim is to delay phase separation for as long as possible. Stability is affected by several factors, such as the composition and size of the globules, viscosity, volume of the phases, $\mathrm{pH}$, presence of electrolytes, osmotic gradient and the properties of the interfacial film formed (Ferrari, Rocha-Filho, 2011; Poyato et al., 2013). Changes in these rheological properties may represent important early predictors of impending failure of the products.

The aim of this work was to develop $\mathrm{O} / \mathrm{W}$ sunscreens emulsions containing açai glycolic extract and, evaluate both their physical stability and the photoprotective efficacy by the testing in vivo Sun Protection Factor (SPF) and determination of Protection Factor of UVA (PF-UVA).

\section{MATERIAL AND METHODS}

\section{Material}

Diethylamino hydroxybenzoyl hexyl benzoate, bis-ethylhexyloxyphenol methoxyphenyl triazine and 
ethylhexyl triazone from BASF SA (São Paulo - SP, Brazil), Octocrylene, benzophenone - 3, ethylhexyl methoxycinnamate, sodium polyacrylate, and phenoxyethanol (and) caprylyl glycol were donated by Ashland Inc. (São Paulo - SP, Brazil), Acrylates/C 10-30 alkyl acrylate crosspolymer, Carbomer (Lubrizol of Brazil Ltda Additives, São Paulo -SP, Brazil), polyacrylamide (and) C 13-14 isoparaffin (and) Laureth-7 (Chemyunion Chemical Ltda, Sorocaba - SP, Brazil), caprylic/capric triglyceride, ethylhexyl stearate, ethylhexyl palmitate, PPG-3 benzyl ether myristate were donated by Croda of Brazil Ltda (Campinas - SP, Brazil), propylene glycol, disodium EDTA, BHT, and triethanolamine, (DEG Import of chemicals, Sorocaba -SP, Brazil), açai glycolic extract (Euterpe oleracea Fruit Extract, batch PR0D016027) was donated by Mapric Farmacocosméticos Products Ltda (São Paulo - SP, Brazil), and distilled water.

\section{Method of preparation and formulations}

The emulsion preparation techniques were dependent on the polymeric surfactant used.

For emulsions formulation containing acrylates/C 10-30 alkyl acrylate crosspolymer (P1 - P3, Table I): polymeric surfactant dispersion was performed using an indirect method, i.e., the acrylates/C 10-30 Alkyl Acrylate Crosspolymer was added into the oil phase (Lima et al., 2008; Pianovski et al., 2008). The oil and water phases were then heated separately to $70 \pm 2{ }^{\circ} \mathrm{C}$. The oil phase was added to the aqueous phase, followed by agitation at $500 \mathrm{rpm}$ (IKA, mod. Digital RW 20, Germany) until the system was naturally cooled to $40 \pm 2{ }^{\circ} \mathrm{C}$. The açai glycolic extract was added to the formulation and the system homogenized ( $500 \mathrm{rpm}$ ) for $5 \mathrm{~min}$.

For preparation of the formulations containing acrylates/C 10-30 alkyl acrylate crosspolymer with the Carbomer (PC1 - PC3 - Table I): the Carbomer was dispersed in the aqueous phase by under mechanical stirrer (Ika, mod. digital RW 20, Germany) at $900 \mathrm{rpm}$ at ambient temperature. The oil phase (containing acrylates/C 10-30 alkyl acrylate crosspolymer) was heated to $60 \pm 2{ }^{\circ} \mathrm{C}$, and added to the aqueous phase. After complete phase oil introduction, stirring was maintained for $15 \mathrm{~min}$ at 900 $\mathrm{rpm}$. The açai glycolic extract was added and the system maintained under stirring at $5 \mathrm{~min}$ to $900 \mathrm{rpm}$. The same preparation method was performed for formulations containing acrylates/C 10-30 alkyl acrylate crosspolymer with polyacrylamide (and) C 13-14 isoparaffin (and) Laureth-7 (PS1 - PS3 - Table I).

For sodium polyacrylate (R1 - R3, Table I) emulsion preparations: the polymeric surfactant was dispersed in the aqueous phase by a mechanical stirrer (Ika, mod. digital RW 20, Germany) at $500 \mathrm{rpm}$ at ambient temperature for $25 \mathrm{~min}$. The oil phase was heated to $50 \pm 2{ }^{\circ} \mathrm{C}$, and added to the aqueous phase. After complete phase oil introduction, stirring was maintained for $10 \mathrm{~min}$ at $900 \mathrm{rpm}$. The açai glycolic extract was added and the system maintained under stirring at $5 \mathrm{~min}$ to $900 \mathrm{rpm}$.

The formulations were produced in three batches.

\section{Preliminary stability tests}

Centrifugation test: centrifugation was performed on $24 \mathrm{~h}$ - old preparation at $3000 \mathrm{rpm}$ (Fanen, mod. 206 $\mathrm{BL}$, Brazil) for $30 \mathrm{~min}$. at room temperature (Lima et al., 2008). The appearance, homogeneity and organoleptic characteristics were evaluated by macroscopic analyses (Ferrari, Rocha-Filho, 2011).

Thermal stress: emulsions were submitted to a heated thermostatic bath (Logen Scientific, mod. LSBMLS 2006-2, Brazil) set for the temperature range of 40 to $80^{\circ} \mathrm{C}$, with temperature increase at intervals of $5{ }^{\circ} \mathrm{C}$, and holding at each temperature for $30 \mathrm{~min}$. The organoleptic characteristics, $\mathrm{pH}$ value determination, electrical conductivity measures, and viscosity, were obtained to evaluate the formulations before and at the end at $80^{\circ} \mathrm{C}$, after the natural cooling of the samples at room temperature $\left(25 \pm 2{ }^{\circ} \mathrm{C}\right)$ (Braconi et al., 1995).

Freeze-defrost cycles: samples were subjected to $4 \pm 2{ }^{\circ} \mathrm{C} / 24$ hours (Mabe, mod. REMB 460, Brazil) and then $45 \pm 2{ }^{\circ} \mathrm{C} / 24$ hours (Fanen, mod. 515, Brazil), thus completing a cycle. The organoleptic characteristics, $\mathrm{pH}$ value determination, electrical conductivity measures, and viscosity were obtained to evaluate the formulations before and at the end of the sixth cycle (12th day) (Lima et al., 2008).

pH value determination: $1.0 \mathrm{~g}$ of emulsion and $9.0 \mathrm{~g}$ of distilled water were placed in a test tube and homogenized. The $\mathrm{pH}$ value (Hanna Instruments, mod. HI 21, Brazil) was determined by inserting the electrode directly into the aqueous dilution $1: 10(\mathrm{w} / \mathrm{w})$ of the sample (Davis, 1977).

Electrical conductivity determination: electrical conductivity measures (Logen Scientific, mod. CD$300-\mathrm{K} 1$, Brazil) were evaluated at a temperature of $25 \pm$ $2{ }^{\circ} \mathrm{C}$ by inserting the electrode directly into the sample (Pianovski et al., 2008).

Viscosity determination: viscosity determinations were obtained using a model DV-III Brookfield rotational rheometer (Stoughton, MA, USA) with cone-plate configuration and linked to a Brookfield software program 


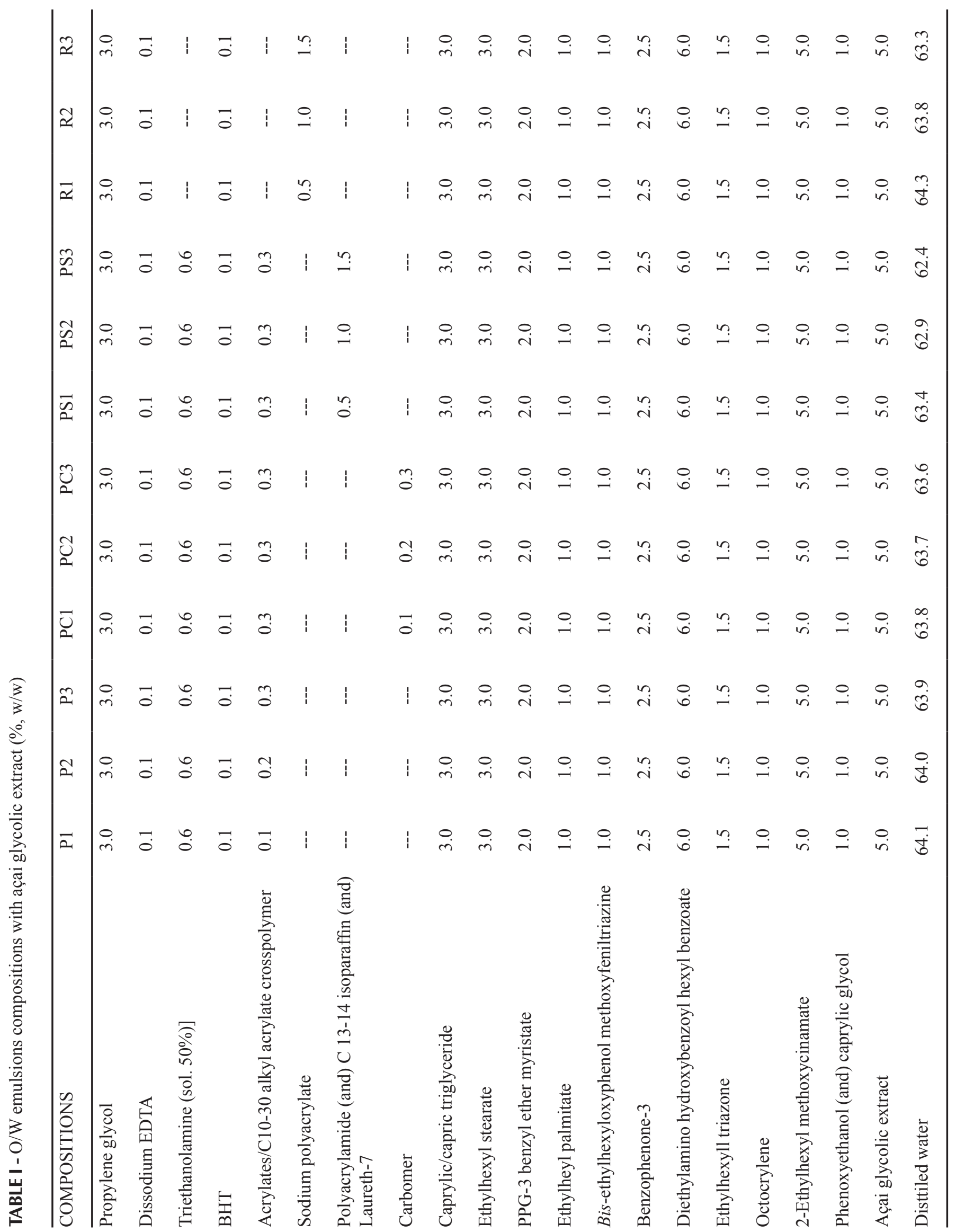


(Rheocalc version 3.0). Rheological parameters were determined at $25 \pm 2{ }^{\circ} \mathrm{C}$ using a CP 52 spindle $(d=12 \mathrm{~mm}$, $\left.\theta=3.0^{\circ}\right)$ and $0.5 \mathrm{~g}$ of each sample. Rheogram curves constructed with ascendant and descendant segments were obtained with progressively increasing $(1-10 \mathrm{rpm})$ as well as gradually decreasing $(10-1 \mathrm{rpm})$ rotation speeds. The measurements were made at intervals of $2 \mathrm{rpm}$, remaining at each speed of rotation for $10 \mathrm{~s}$. For accelerated stability tests, the values obtained were used to calculate the flow index and hysteresis area. Three batches were prepared and measurements repeated three times for each sample (Lima et al., 2008).

\section{Accelerated stability tests}

The samples considered stable by preliminary tests were stored under different conditions: $4 \pm 2{ }^{\circ} \mathrm{C}$ (Mabe, mod. REMB 46, Brazil); $25 \pm 2{ }^{\circ} \mathrm{C}$ (ambient temperature), $37 \pm 2{ }^{\circ} \mathrm{C}$ and $75 \pm 5 \%$ relative humidity (RH) (Nova Etica, mod. 520-CLDTS 150, Brazil) and $45 \pm 2{ }^{\circ} \mathrm{C}$ and $75 \pm 5 \%$ RH (Nova Etica, mod. 520-CLDTS 150, Brazil). The samples were maintained under these conditions for 90 days. The macroscopic analyses (appearance, homogeneity and organoleptic characteristics), $\mathrm{pH}$ value determinations and rheological behavior (minimal apparent viscosity, rheogram curves, flow index and hysteresis area) were evaluated at different time intervals (24 $\mathrm{h}$ after preparation of formulations and on $30^{\text {th }}, 60^{\text {th }}$ and $90^{\text {th }}$ days) (Ferrari, Rocha-Filho, 2011).

\section{Statistical analyses}

Statistical analyses of the preliminary and accelerated stability data were performed using the analysis of normality of the sampling distribution, evaluated by parametric analysis of variance (ANOVA) as well as the Tukey test $(\mathrm{p}<0.05)$ (Ferrari, Rocha-Filho, 2011) using SPSS 13.0 for Windows.

\section{In vivo Sun Protection Factor (SPF) determination}

The $\mathrm{O} / \mathrm{W}$ emulsions containing the same concentration of sunscreens with and without açai glycolic extract were evaluated.

The in vivo SPF was determined according to the International Sun Protection Factor Test Method - 2006 (Colipa, 2006). A standard sunscreen formulation of methodology (Colipa, 2006) containing 7\% of PABA and $3 \%$ of benzophenone 3 was used as control.

The results were expressed by the mean and standard deviation of the analyses of ten volunteers.
The research protocol was approved by the Human Experimentation Committee of the University of Cuiabá, under protocol \# 2011-123. Wilcoxon non parametric tests were used to determine statistical significance $(\mathrm{p}<0.05)$.

\section{In vitro UVA Protection Factor (FP-UVA) determination}

$\mathrm{O} / \mathrm{W}$ sunscreen emulsions with and without açai glycolic extract were applied $\left(1.3 \mathrm{mg} / \mathrm{cm}^{2}\right)$ to roughened polymethylmethacrylate PMMA Helioplates HD6 plates $\left(50 \times 50 \times 2.5 \mathrm{~mm}, \mathrm{~S}_{\mathrm{a}}=2 \mu \mathrm{m}\right.$, Helioscience, France) and distributed evenly over the whole surface using a coated finger. For each formulation, three plates were prepared and measurements repeated three times for each sample. The plates were left to equilibrate in a dark place under ambient temperature for $15 \mathrm{~min}$. UV transmission measurements between 290 and $400 \mathrm{~nm}$ were performed using a spectrophotometer equipped with an integrating sphere (UV Transmittance Analyzer UV - 1000S, Labsphere, USA). The in vitro PF - UVA, critical wavelength $\left(\lambda_{\mathrm{c}}\right)$ and SPF/PF-UFA were evaluated according to the In vitro method for determination of the UVA protection factor and "critical wavelength" values of sunscreen products (Colipa, 2011; Brasil, 2012).

Comparison of the formulations with and without the açai glycolic extract was performed using the Student t-test $(\mathrm{p}<0.05)$ for independent variables (Statistic Program version 9.0).

\section{RESULTS AND DISCUSSION}

\section{Preliminary stability tests}

The preliminary stability studies are used to delineate the initial phase of product development. These studies use extreme and different conditions to accelerate the potential reactions between components and demonstrate the most common instability processes of emulsions (phase separation, flocculation and creaming) (Tcholakova et al., 2006). The conditions of these studies are not intended to estimate product shelf-life, but to provide the formulation screening (Lima et al., 2008).

In the present study, formulations were prepared containing polymeric surfactants acrylates/C 10-30 alkyl acrylate crosspolymer (P1-P3) or sodium polyacrylate (R1-R3) at different concentrations (Table I). These polymers have hydrophobic groups with similar amphoteric structures as surfactants and act by an electrosteric stabilization mechanism, which represent a 
combination of electrical repulsion and steric stabilization (Lochead et al., 1986; Hemker, 1990).

Macroscopically the P1 and P2 emulsions showed phase separation within 24 hours of preparation. The P3 (0.3\% acrylates/C $10-30$ alkyl acrylate crosspolymer) emulsion and formulations containing sodium polyacrylate (R1, R2 and R3; 0.5, 1.0 and $1.5 \%$ respectively) proved macroscopically stable. Previous studies have reported the use of polymeric surfactants in stabilizing emulsified systems due to their conformation, stabilization mechanisms, good skin compatibility and use at low concentrations (Tadros, 2004; Lima et al., 2008; Pianovski et al., 2008).

The influence of the two thickeners and rheology modifiers on P 3 stability was investigated using polyacrylamide (and) C13-14/isoparaffin (and) Laureth-7 (PS1-PS3) and Carbomer (PC1-PC3) (Table I). All these formulations were stable on macroscopic analyses.

The emulsions (Table I) had beige color, açai glycolic extract odor and a homogenous creams consistency.

The centrifugation test was performed for the macroscopically stable emulsions. No phase separation or organoleptic characteristic changes were observed after centrifugation for any of the samples (Table II).

The addition of rheology modifiers can increase the stability of emulsions. Ferrari and Rocha-Filho (2011) demonstrated that the association between the polymeric surfactants and rheology modifier improved the stabilization of emulsion on the centrifugation test. According to Tadros (2004) the absence of rheology modifier in the formulations resulted in phase separation after centrifugation because there was an insufficient increase in the viscosity of the external phase of the vehicles to maintain the integrity of the emulsions.

The emulsions tested in this study were then subjected to thermal stress and freeze-defrost cycle (Table II).

The PC2, PS 1 and R3 formulations showed statistically significant differences $(p<0.05)$ after the freeze-defrost cycle when compared with initial $\mathrm{pH}$ values (Table II).

Monitoring the $\mathrm{pH}$ value is crucial for determining the stability of emulsions. In fact, $\mathrm{pH}$ changes indicate the occurrence of chemical reactions. Changes in $\mathrm{pH}$ may

TABLE II - Results of preliminary stability tests of emulsions containing açai glycolic extract

\begin{tabular}{|c|c|c|c|c|c|c|c|c|c|c|}
\hline PARAMETERS & P3 & PC1 & PC2 & PC3 & PS1 & PS2 & PS3 & R1 & $\mathbf{R 2}$ & R3 \\
\hline \multicolumn{11}{|l|}{ AFTER 24h } \\
\hline Centrifugation & $\mathrm{N}$ & $\mathrm{N}$ & $\mathrm{N}$ & $\mathrm{N}$ & $\mathrm{N}$ & $\mathrm{N}$ & $\mathrm{N}$ & $\mathrm{N}$ & $\mathrm{N}$ & $\mathrm{N}$ \\
\hline Electrical conductivity (mS) & $\begin{array}{c}623 \\
( \pm 62)\end{array}$ & $\begin{array}{c}594 \\
( \pm 40)\end{array}$ & $\begin{array}{c}608 \\
( \pm 33)\end{array}$ & $\begin{array}{c}594 \\
( \pm 30)\end{array}$ & $\begin{array}{c}775 \\
( \pm 90)\end{array}$ & $\begin{array}{c}977 \\
( \pm 25)\end{array}$ & $\begin{array}{l}1,179 \\
( \pm 33)\end{array}$ & $\begin{array}{c}929 \\
( \pm 81)\end{array}$ & $\begin{array}{l}1,566 \\
( \pm 38)\end{array}$ & $\begin{array}{c}1,924 \\
( \pm 142)\end{array}$ \\
\hline \multicolumn{11}{|l|}{ AFTER TS } \\
\hline $\mathrm{pH}$ value & $\begin{array}{c}6.92 \\
( \pm 0.06)\end{array}$ & $\begin{array}{c}6.44 \\
( \pm 0.32)\end{array}$ & $\begin{array}{c}6.14 \\
( \pm 0.16)\end{array}$ & $\begin{array}{c}5.85 \\
( \pm 0.15)\end{array}$ & $\begin{array}{c}7.01 \\
( \pm 0.17)\end{array}$ & $\begin{array}{c}6.68 \\
( \pm 0.11)\end{array}$ & $\begin{array}{c}6.84 \\
( \pm 0.19)\end{array}$ & $\begin{array}{c}6.84 \\
( \pm 0.22)\end{array}$ & $\begin{array}{c}6.78 \\
( \pm 0.15)\end{array}$ & $\begin{array}{c}6.68 \\
( \pm 0.18)\end{array}$ \\
\hline \multicolumn{11}{|l|}{ AFTER FDC } \\
\hline pH value & $\begin{array}{c}6.93 \\
( \pm 0.12)\end{array}$ & $\begin{array}{c}6.42 \\
( \pm 0.29)\end{array}$ & $\begin{array}{c}6.09 \\
( \pm 0.15)^{*}\end{array}$ & $\begin{array}{c}5.78 \\
( \pm 0.13)\end{array}$ & $\begin{array}{c}7.02 \\
( \pm 0.14)^{*}\end{array}$ & $\begin{array}{c}6.74 \\
( \pm 0.10)\end{array}$ & $\begin{array}{c}6.87 \\
( \pm 0.07)\end{array}$ & $\begin{array}{c}6.92 \\
( \pm 0.14)\end{array}$ & $\begin{array}{c}6.81 \\
( \pm 0.12)\end{array}$ & $\begin{array}{c}6.79 \\
( \pm 0.15)^{*}\end{array}$ \\
\hline Electrical conductivity (mS) & $\begin{array}{l}590 * \\
( \pm 65)\end{array}$ & $\begin{array}{c}566 \\
( \pm 104)\end{array}$ & $\begin{array}{c}645 \\
( \pm 22)\end{array}$ & $\begin{array}{c}629 \\
( \pm 33)\end{array}$ & $\begin{array}{c}650 \\
( \pm 230)\end{array}$ & $\begin{array}{l}1,016 \\
( \pm 75)\end{array}$ & $\begin{array}{l}1,224 \\
( \pm 94)\end{array}$ & $\begin{array}{l}996^{*} \\
( \pm 55)\end{array}$ & $\begin{array}{c}1,623 \\
( \pm 123)\end{array}$ & $\begin{array}{c}2,320 \\
( \pm 1009)\end{array}$ \\
\hline Viscosity (cP) & $\begin{array}{c}1,973 \\
( \pm 154)\end{array}$ & $\begin{array}{l}3,458^{*} \\
( \pm 541)\end{array}$ & $\begin{array}{c}5,632 \\
( \pm 328)\end{array}$ & $\begin{array}{c}6,956 \\
( \pm 390)\end{array}$ & $\begin{array}{l}3,235^{*} \\
( \pm 332)\end{array}$ & $\begin{array}{c}4,914 \\
( \pm 322)\end{array}$ & $\begin{array}{c}7,694 \\
( \pm 438)\end{array}$ & $\begin{array}{c}1,863 \\
( \pm 594)\end{array}$ & $\begin{array}{c}8,308 \\
( \pm 267)\end{array}$ & $\begin{array}{c}6,892 * \\
( \pm 1684)\end{array}$ \\
\hline
\end{tabular}

$\mathrm{FDC}=$ Freeze-Defrost Cycles; TS $=$ Thermal Stress; $\mathrm{N}=$ Normal. ${ }^{*} \mathrm{p}<0.05$ compared to the initial time. Data were expressed as mean \pm Standard Deviation (SD). $\mathrm{n}=9$. 
also indicate chemical decomposition of the formulation components (Leonardi et al., 2000) and promote changes in other physicochemical properties such as viscosity (Frange, Garcia, 2009). This situation most likely occurred for the formulations PS1 and R3 indicating the instability of these systems.

According to Pearce and Kinsella (1978) and Kato et al. (1985), electrical conductivity is often used to determine the type of emulsion and to control its stability during the storage period. The conductivity measure can be used to check the integrity of the external phase (Pianovski et al., 2008).

A statistically significant change in the electrical conductivity values of P3, PS3, R1 and R3 was observed (Table II). This situation may be considered a sign of the instability of the emulsion. According Masmoudi et al. (2005) there is not a linear relationship between the increase or decrease in conductivity and the instability, therefore other adjuvant methods should be used to evaluate the stability.

Viscosity is a parameter that determines whether a product exhibits the proper consistency and fluidity and can indicate if stability is adequate; in other words, it provides an indication of the behavior of the product over time (Anvisa, 2004).

The formulations PC1, PS1, R1 and R3, exhibited significant variations for viscosity in the preliminary stability studies (Table II).

PC1 and PS1 emulsions showed a decrease in viscosity after thermal stress and after the freeze-defrost cycle compared to the initial viscosity (Table II). Decreases in viscosity may be a sign of instability (Masmoudi et al., 2005). R1 and R3 emulsions showed increased viscosity after the freeze-defrost cycle and after thermal stress compared to the initial viscosity (Table II). This can occur due to evaporation of water from the formulations during storage (Leonardi et al., 2000).

PC3, PS2 and R2 formulations were considered stable under conditions of preliminary stability tests and were therefore evaluated by the accelerated stability tests.

\section{Accelerated stability tests}

Accelerated stability tests employ less extreme conditions compared to the previous test. The accelerated tests may be used to estimate shelf-life of the product (Baby et al., 2008).

The organoleptic characteristics evaluation assesses by means of comparative analyses, the changes with respect to color, odor and appearance. These analyses indicate the similarities of the emulsions subjected to the stability tests in relation to the emulsions that have been recently formulated, independent of the conditions and storage periods (Calero et al., 2013). After the accelerated stability test, all of the formulations (PC3, PS2 and R2) maintained their organoleptic characteristics: beige color, açai glycolic extract odor and homogenous cream consistency.

The PS2 formulation showed significant variations in the parameters of $\mathrm{pH}$ and viscosity after 90 days of storage at different temperatures. Other studies (Anchisi et al., 2001; Gonçalves, Maia Campos, 2009) have reported the development of stable emulsions containing this same polymer (polyacrylamide (and) C 13-14 isoparaffin (and) Laureth-7) at concentrations higher than $2 \%$.

The $\mathrm{pH}$ value of the PC3 formulation remained stable throughout the duration of the study, but statistically significant changes in viscosity values were observed. According to the technical literature (Lubrizol, 2007), this polymer is more vulnerable to ions, such as the salts found in surfactants and vegetable extracts.

After application of the accelerated stability tests, only $\mathrm{R} 2$ remained stable. The data are summarized in Table III.

The $\mathrm{pH}$ of the $\mathrm{R} 2$ emulsion was reduced (Table III); however, the changes in these $\mathrm{pH}$ values were no greater than $10 \%$, where its representative $\mathrm{pH}$ remained 6.2 and 6.9 , values compatible with the skin. The degradation of any component of the phytocosmetic may promote a drop in $\mathrm{pH}$ value and promote skin irritation (Isaac et al., 2008). The alteration in the $\mathrm{pH}$ value caused no changes in organoleptic characteristics or viscosity.

No statistically significant changes in the viscosity values were evident over the duration of the experiment (90 days) indicating good stability of the samples. According to Tadros (2004) at decrease or increase in viscosity during storage indicates instability of the system. There were no significant differences in the minimal apparent viscosity among the three batches formulated during the period or among the stress conditions investigated.

The O/W emulsion developed (R2) showed nonNewtonian behavior (Figure 1) given it did not exhibit a non linear relationship between shear stress and shear rate (Tadros, 2004). In addition, the flow index values (Table II) were below 1.0 indicating pseudoplastic flow behavior (Castelli et al., 2008; Mendonça et al., 2009; Ferrari, Rocha-Filho, 2011), a desirable rheological property for cosmetics products (Guaratini, Gianeti, Maia Campos, 2006).

Pseudoplastic behavior is suitable for topical application products where, after shearing, the initial 
TABLE III - $\mathrm{pH}$ value, minimal apparent viscosity, flow index and hysteresis area values of $\mathrm{O} / \mathrm{W}$ emulsion (R2) during accelerated stability studies at different temperatures

\begin{tabular}{lccccc}
\hline Time (days) & Temperature $\left({ }^{\circ} \mathrm{C}\right)$ & $\mathrm{pH}$ value & $\begin{array}{c}\text { Minimal apparent } \\
\text { Viscosity }(\mathrm{cP})\end{array}$ & Flow index & Hysteresis area $(\mathrm{d} / \mathrm{cm} 2 . \mathrm{s})$ \\
\hline $1^{\circ}$ & 25 & $6.9( \pm 0.10)$ & $8,586( \pm 326)$ & $0.35( \pm 0.03)$ & $298.51( \pm 246.44)$ \\
$90^{\circ}$ & 4 & $6.2( \pm 0.04)^{*}$ & $8,933( \pm 676)$ & $0.22( \pm 0.09)$ & $904.64( \pm 728.41)$ \\
& 25 & $6.3( \pm 0.02)^{*}$ & $8,371( \pm 182)$ & $0.26( \pm 0.04)$ & $330.15( \pm 214.17)$ \\
& 37 & $6.3( \pm 0.03)^{*}$ & $8,374( \pm 270)$ & $0.23( \pm 0.08)$ & $265.41( \pm 177.57)$ \\
& 45 & $6.3( \pm 0.02)^{*}$ & $8,030( \pm 193)$ & $0.28( \pm 0.06)$ & $321.08( \pm 187.28)$ \\
\hline
\end{tabular}

$* \mathrm{p}<0.05$. Data were expressed as mean \pm Standard Deviation (SD). $(\mathrm{n}=9)$.

resistance to the emulsion flow decreases, reflected in ease of application. A decrease in viscosity shear indicates thixotropy. Thixotropy is a term used to describe an isothermal system, in which the apparent viscosity decreases under shear stress, followed by a gradual recovery when the stress is removed (Tadros, 2004; Lee, Moturi, Lee, 2009).

Thixotropic products become more fluid when subjected to an external pressure, and spread more easily in the region where they are applied, where the initial viscosity recovers when the application ceases (Tadros, 2004). The rheograms (Figure 1) showed the descending curve was below that of the ascending curve, and the hysteresis area (Table III) indicates thixotropy in the systems.

\section{Sun Protection Factor Study (SPF)}

Vegetal substances have recently been considered as potential resources for sunscreen formulations due to their UV spectrum absorption and antioxidant properties (Avila Acevedo et al., 2005). Determination of the antioxidant activity of plant extracts has been well described; however, the evaluation of their photoprotective capacity is usually limited by the UV spectrum characteristics and the concentration of the UV-absorbing compounds (Hupel, Poupart, Ar Gall, 2011).

Given the structural similarities between polyphenolic compounds and organic UV filters, in addition to the antioxidant activity of these bioactive compounds, they might exert photoprotective activity (Velasco et al., 2008a; Velasco et al., 2008b; Violante et al., 2009).

The in vivo $\mathrm{SPF}$ values of the $\mathrm{O} / \mathrm{W}$ sunscreen emulsion containing $1.0 \%$ of sodium polyacrylate (R2) are summarized in Table IV.

There was no statistically significant difference in the in vivo SPF values obtained $(\mathrm{p}<0.05)$, demonstrating

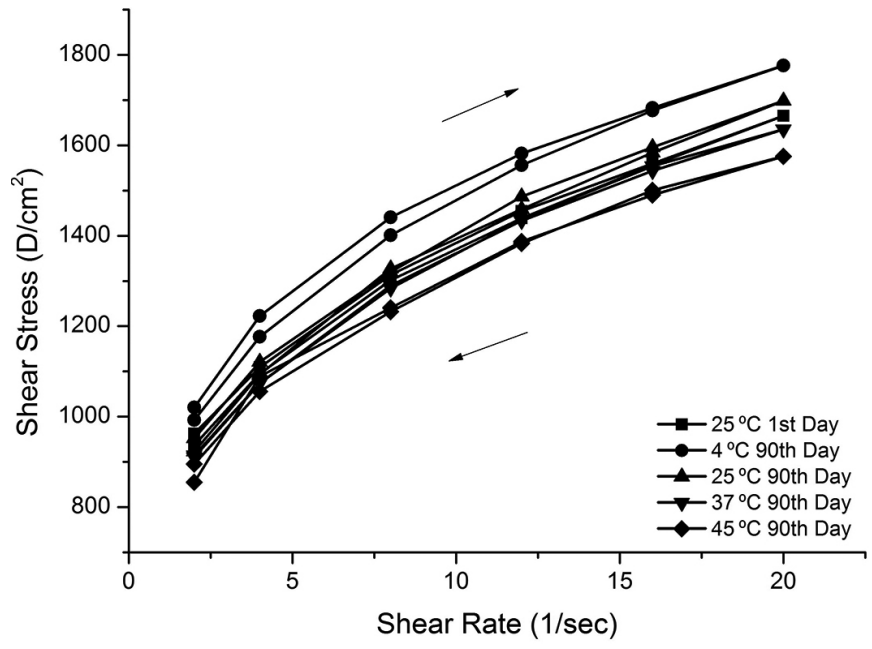

FIGURE 1 - Flow behavior for a stable O/W sunscreens emulsion (R2) $24 \mathrm{~h}$ and ninety days after preparation at different temperatures.

that the açai glycolic extract, at the concentration used, was unable to exert synergistic action when associated with UV filters. Other researchers (Dondi, Albini, Serpone, 2006; Velasco et al., 2008b) have reported that the association of UV filters with bioactive compounds in a complex medium, such as an emulsion, leads to a distinctive photochemical profile, different from the photochemistry of the isolated compounds.

According to Velasco et al. (2008b) bioactive compounds interact with UV filters and their photoprotective efficacy may be dependent on the nature of the bioactive compound and UV filter concentrations.

The SPF results obtained in our experimental study are consistent with findings reports in previous studies (Silva et al., 2005; Souza et al., 2005; Lopes et al., 2007; Violante et al., 2009; Ferrari, Rocha-Filho, 2011; Mansur et al., 2012). The cited studies described the difficulty in increase in the SPF value by the addition of natural active agents in the formulation containing chemical and/or 
TABLE IV - The in vivo sun protection factor (SPF) values of the O/W sunscreen emulsion containing $1.0 \%$ of sodium polyacrylate (R2)

\begin{tabular}{lcc}
\hline Formulation & SPF $(\overline{\mathrm{X}})$ & Standard Deviation $(\mathrm{SD})$ \\
\hline Sunscreen emulsion with açai glycolic extract & 25.3 & \pm 4.5 \\
Sunscreen emulsion without açai glycolic extract & 22.5 & \pm 2.4 \\
Standard Sunscreen Formulation - Control & 16.7 & \pm 3.4 \\
\hline
\end{tabular}

Data were expressed as mean $(\overline{\mathrm{X}}) \pm$ Standard Deviation $(\mathrm{SD}) . \mathrm{n}=10$.

physical UV filters. When the $P$. incarnate L. dry extract interacted negatively with UV filters and led to reduction if the SPF value, Velasco et al. (2008b) attributed this behavior to four main factors: presence of inorganic UV filter; composition of the vehicle; quantitative composition of the organic UV filter; and phytochemical composition of the extracts. These last three factors may explain why the açai glycolic extract failed to promote an the increase in the SPF value.

The antioxidant properties of açai have been previously described in the literature (Kuskoski et al., 2006; Kang et al., 2011; Gordon et al., 2012; Inácio et al., 2013). However, although incorporation of açai glycolic extracts into sunscreen emulsion did not increase SPF in vivo, this formulation may be effective as an antioxidant cosmetic product.

\section{In vitro UVA Protection Factor (FP-UVA) determination}

To provide protection against UVB and UVA radiation, the sunscreen products should contain not only UVB filters but also one or more UVA filters. UVA protection has been recognized as essential and has become a target for improving sunscreen efficacy (Hojerová, Medovcíková, Mikula, 2011; Sambandan, Ratner, 2011).

The in vitro UVA protection factor (PF-UVA) values, SPF/PF-UVA and the critical wavelength $(\lambda c)$ determinations are reported in Table $\mathrm{V}$.
There was no significant difference $(\mathrm{p}<0.05)$ in the PF-UVA values between formulations with and without açai extract, indicating that açai glycolic extract, at the concentration used, was unable to increase the UVA protection.

Brazilian legislation (Brasil, 2012) recommends that the PF-UVA for sunscreen products should be at least $1 / 3$ of the SPF and that SPF/PF-UVA value should be $\leq 3$. Our experimental results are in accordance with the requirements of Brazilian legislation (Brasil, 2012) and European Commission Recommendations (European Commission, 2006).

According to Wang, Osterwalder, and Jung (2011), topical application of antioxidant compounds associated with UV filters may neutralize the free radicals induced by UV radiation. Wang and col. (2011) reported that a product with a high PF-UVA absorbs most of the harmful radiation in the UVA spectrum reducing the amount of free radicals generated in the skin.

Other studies have been performed with the aim of increasing UVA protection using natural products (Rancan et al., 2002; Baby et al., 2008; Velasco et al., 2008b; Lohézic-Le Dévéhat et al., 2013).

The critical wavelength value for the test product is defined as that wavelength where the area under the absorbance spectrum for the irradiated product from $290 \mathrm{~nm}$ to critical wavelength is $90 \%$ of the integral of absorbance spectrum from $290 \mathrm{~nm}$ to $400 \mathrm{~nm}$ (Colipa, 2011). According to Brazilian legislation (Brasil, 2012) and the European Cosmetics Association (Colipa, 2011)

TABLE V - In vitro UVA protection factor (PF-UVA), SPF/PF-UVA and critical wavelength (nm) determinations of the O/W sunscreen emulsion with (R2) and without açai glycolic extract

\begin{tabular}{lccc}
\hline & $\begin{array}{c}\text { Formulation without açai } \\
\text { glycolic extract }\end{array}$ & $\begin{array}{c}\text { Formulation with açai } \\
\text { glycolic extract }\end{array}$ & $\begin{array}{c}\text { Reference sunscreen } \\
\text { formulation }\end{array}$ \\
\hline PF-UVA & $13.38( \pm 0.52)$ & $14.97( \pm 0.44)$ & $14.02( \pm 0.16)$ \\
SPF/PF-UVA & $1.68( \pm 0.06)$ & $1.69( \pm 0.05)$ & $1.14( \pm 0.01)$ \\
Critical wavelength & 378 & 378 & --- \\
\hline
\end{tabular}

Data were expressed as mean ( $\mathrm{n}=3) \pm$ Standard Deviation (SD). 
the critical wavelength should be greater than or equal to $370 \mathrm{~nm}$. As shown in Table V, the critical wavelength values for the two formulations were consistent with those required by Brazilian legislation and the European Cosmetics Association (Colipa, 2011).

When the sunscreen product has a PF-UVA of at least $1 / 3$ of the SPF, an SPF/PF-UVA value $\leq 3$ and a critical wavelength value $\geq 370 \mathrm{~nm}$, it may be labeled as providing "broad spectrum" UVA and UVB protection (Colipa, 2011). The $\mathrm{O} / \mathrm{W}$ sunscreen emulsion developed showed these characteristics, so it may therefore be considered a sunscreen with UVA and UVB protection.

\section{CONCLUSIONS}

The $\mathrm{O} / \mathrm{W}$ sunscreen emulsion with $1 \%$ of sodium polyacrylate (R2) remained stable after preliminary and accelerated stability tests and showed pseudoplastic and thixotropy behavior, important characteristics for a sunscreen product. When açai glycolic extract was added in the emulsion sunscreen (R2), no significant increase in the in vivo SPF value was observed. The sunscreen emulsion containing açai glycolic extract showed a PF-UVA $=14.97,1.69$ of the SPF/PF-UVA ratio and a critical wavelength value of $378 \mathrm{~nm}$. This emulsion may therefore be considered a sunscreen with UVA and UVB protection, according to Brazilian legislation and the European Cosmetics Association. There was no significant difference in the parameters between the formulations with and without açai glycolic extract. The results obtained in this study do not rule out the use of açai glycolic extract in sunscreen formulations. As previously reported in the literature, açai has antioxidant activity, so may be used to protect the skin against damage caused by free radicals induced by UV radiation. However, studies with isolated compounds or dry extract of açai should be performed to evaluate photoprotective activity.

\section{ACKNOWLEDGMENTS}

The authors are grateful Ashland Inc., BASF SA, Chemyunion Chemical Ltda, Croda of Brazil Ltda, Lubrizol of Brazil Ltda Additives and Mapric Farmacocosméticos Produtos Ltda for the donation of sample materials. Authors also would like to thank the Allergisa Pesquisa Dermato Cosmetica Ltda for carrying out the photoprotection efficacy tests. This work was supported by Federal University of Rio Grande do Norte (UFRN) and Conselho Nacional de Desenvolvimento
Científico e Tecnológico (CNPq) and by grants from UFRN/REUNI.

\section{REFERENCES}

AFAQ, F.; MUKHTAR, H. Botanical antioxidants in the prevention of photocarcinogenesis and photoaging. Exp. Dermatol., v.15, n.9, p.678-684, 2006.

AFAQ, F. Natural agents: cellular and molecular mechanisms of photoprotection. Arch. Biochem. Biophys., v.508, n.2, p.144-151, 2011.

ANCHISI, C.; MACCIONI, A.M.; SINICO, C.; VALENTI, D. Stability studies of new cosmetic formulations with vegetable extracts as functional agents. Farmaco, v.56, n.5-7, p.427-431, 2001.

AGÊNCIA NACIONAL DE VIGILÂNCIA SANITÁRIA. ANVISA. Guia de estabilidade de produtos cosméticos. Brasília: Anvisa, 2004. 45 p.

AVILA ACEVEDO, J.G.; CASTAÑEDA, C.M.C.; BENITEZ, F.J.C.; DURÁN, D.A.; BARROSO, V.R.; MARTÍNEZ, C.G.; MUÑOZ, L.J.L.; MARTÍNEZ, C.A.; ROMO DE VIVAR, A. Photoprotective activity of Buddleja scordioides. Fitoterapia, v.76, n.3-4, p.301-309, 2005.

BABY, A.R.; HAROUTIOUNIAN-FILHO, C.A.; SARRUF, F.D.; TAVANTE-JÚNIOR, C.R.; PINTO, C.A.S.O.; ZAGUE, V.; ARÊAS, E.P.G.; KANEKO, T.M.; VELASCO, M.V.R. Estabilidade e estudo de penetração cutânea in vitro da rutina veiculada em uma emulsão cosmética através de um modelo de biomembrana alternativo. Rev. Bras. Ciênc. Farm., v.44, n.2, p.233-248, 2008.

BALAKRISHNAN, K.P.; NARAYANASWAMY, N. Botanicals as sunscreens: their role in the prevention of photoaging and skin cancer. Int. J. Cosmetic Sci., v.1, n.1, p.1-12, 2011.

BIANCHI, A.; MARCHETTI, N.; SCALIA, S. Photodegradation of (-)-epigallocatechin-3-gallate in topical cream formulations and its photostabilization. J. Pharm. Biomed. Anal., v.56, n.4, p.692-697, 2011.

BOBIN, M.F.; RAYMOND, M.; MARTINI, M.C. UVA/ UVB absorption properties of natural products. Cosmet. Toiletries, v.109, n.11, p.63-70, 1994. 
BRACONI, F.L.; OLIVEIRA, I.S.; BARONI, M.N.F.; ROCHA FILHO, P.A. Aplicação cosmética do óleo de canola, In: Congresso Latino Americano e Ibérico de Químicos Cosméticos. Congresso Latino Americano e Ibérico de Químicos Cosméticos, 12. Anais. São Paulo: Associação Brasileira de Cosmetologia, p. 6-19, 1995.

BRASIL. Resolução n ${ }^{\circ} .30$, de 2012. Diário Oficial da União, Brasília, DF, 4 de jun. de 2012. Seção 1, p. 83.

CAlero, N.; MUÑOZ, J.; COX, P.W.; HeUER, A.; GUERRERO, A. Influence of chitosan concentration on the stability, microstructure and rheological properties of $\mathrm{O} / \mathrm{W}$ emulsions formulated with high-oleic sunflower oil and potato protein. Food Hydrocolloid., v.30, n.1, p.152$162,2013$.

CASTELLI, V.C.; MENDONÇA, C.C.; CAMPOS, M.A.L.; FERRARI M.; MACHADO S.R.P. Development and evaluation of the preliminary stability of $\mathrm{O} / \mathrm{W}$ emulsion containing ketoconazole 2.0\%. Acta Sci. Health Sci., v.30, n.2, p.121-128, 2008.

CLIFF, M.A.; KING, M.C.; SCHLOSSER, J. Anthocyanin, phenolic composition, colour measurement and sensory analysis of BC commercial red wines. Food Res. Int., v.40, n.1, p.92-100, 2007.

COLIPA. Guideline. International Sun Protection Factor (SPF) test method. 2006. Available at: $<$ https://www. cosmeticseurope.eu/publications-cosmetics-europeassociation/guidelines.html? view $=$ item\&id=21>. Accessed on: May 2013.

COLIPA. Guideline. In vitro UV protection method task force: in vitro method for the in vitro determination of UVA protection factor and "critical wavelength" values of sunscreen products. 2011. Available at: $<$ http://www.ctfa. org.nz/documents/members>. Accessed on: May 2013.

DAVIS, H.M. Analysis of creams and lotions. In: SENSEL, A.J. (Ed.). Newburger's manual of cosmetic analysis. Washington: Association Official Analytical Chemists, 1977. chap.4, p.32.

DONDI, D.; ALBINI, A.; SERPONE, N. Interactions between differrent solar UVA/UVB filters contained in commercial sunscreens and consequent loss of UV protection. Photochem. Photobiol. Sci., v.5, n.9, p.835-843, 2006.
EL GHISSASSI, F.; BAAN, R.; STRAIF, K.; GROSSE, Y.; SECRETAN, B.; BOUVARD, V.; BENBRAHIMTALLAA, L.; GUHA, N.; FREEMAN, C.; GALICHET, L.; COGLIANO, V. WHO International Agency for Research on Cancer Monograph Working Group. A review of human carcinogens--part D: radiation. Lancet Oncol., v.10, n.8, p.751-752, 2009.

EUROPEAN Commission Reccomandation on the efficacy of sunscreen products and the claims mode relating thereto. Official Journal of the European Union, v.265, p.39-43, 2006.

FERRARI, M.; ROCHA-FILHO, P.A.D. Multiple emulsions containing amazon oil: açaí oil (Euterpe oleracea). Rev. Bras. Farmacogn., v.21, n.4, p.737-743, 2011.

FRANGE, R.C.C.; GARCIA, M.T.J. Development of olive oil-in-water emulsions: Assessment of physical stability. Rev. Ciênc. Farm. Básica Apl., v.30, n.3, p.263-271, 2009.

GANDINI, S.; SERA, F.; CATTARUZZA, M.S.; PASQUINI, P.; PICCONI, O.; BOYLE, P.; MELCHI, C.F. Metanalysis of risk factors for cutaneous melanoma: II. Sun exposure. Eur. J. Cancer, v.41, n.1, p.45-60, 2005.

GONÇALVES, G.M.S.; MAIA CAMPOS, P.M.B.G. Shelf life and rheology of emulsions containing vitamin $\mathrm{C}$ and its derivatives. Rev. Ciênc. Farm. Básica Apl., v.30, n.2, p.217-224, 2009.

GORDON, A.; CRUZ, A.P.G.; CABRAL, L.M.C.; FREITAS, S.C.; TAXI, M.A.D.; DONANGELO, C.M.D.; MATTIETTO, R.A.; FRIEDRICH, M.; MATTA, V.M.; MARX, F. Chemical characterization and evaluation of antioxidant properties of Açaí fruits (Euterpe oleraceae Mart.) during ripening. Food Chem., v.133, n.2, p.256-263, 2012.

GUARATINI, T.; GIANETI, M.D.; MAIA CAMPOS, P.M.B.G. Stabilitiy of cosmetic formulations containing esters of vitamins E and A: chemical and physical aspects. Int. J. Pharm., v.327, n.1-2, p.12-16, 2006.

HEMKER, W.J. Universal oil-in-water polyeletrolyte emulsifiers for advanced cosmetic product formulation. Sofw, v.116, n.14, p.505-508, 1990. 
HOJEROVÁ, J.; MEDOVCÍKOVÁ, A.; MIKULA, M. Photoprotective efficacy and photostability of fifteen sunscreen products having the same label SPF subjected to natural sunlight. Int. J. Pharm., v.408, n.1-2, p.27-38, 2011.

HUPEL, M.; POUPART, N.; AR GALL, E. Development of a new in vitro method to evaluate the photoprotective sunscreen activity of plant extracts against high UV-B radiation. Talanta, v.86, p.362-371, 2011.

INÁCIO, M.R.C.; LIMA, K.M.G.; LOPES, V.G.; PESSOA, J.D.C.; TEIXEIRA, G.H.A. Total anthocyanin content determination in intact açaí (Euterpe oleracea Mart.) and palmitero-juçara (Euterpe edulis Mart.) fruit using near infrared spectroscopy (NIR) and multivariate calibration. Food Chem., v.136, n.3-4, p.1160-1164, 2013.

INSTITUTO NACIONAL DO CANCER. INCA. INCA $e$ Ministério da Saúde apresentam estimativas de câncer para 2014. Available at: < http://www2.inca.gov.br/wps/wcm/ connect/agencianoticias/site/home/noticias/2013/inca ministerio_saude_apresentam_estimativas_cancer_2014>. Accessed on: 03 Jan. 2014.

ISAAC, V.L.B.; CEFALI, L.C.; CHIARI, B.G.; OLIVEIRA, C.C.L.G.; SALGADO H.R.N.; CORREAA, M.A. Protocolo para ensaios físico-químicos de estabilidade de fitocosméticos. Rev. Ciênc. Farm. Básica Apl., v.29, n.1, p.81-96, 2008.

KANG, J.; XIE, C.; LI, Z.; NAGARAJAN, S.; SCHAUSS, A.G.; WU, T.; WU, X. Flavonoids from acai (Euterpe oleracea Mart.) pulp and their antioxidant and anti-inflammatory activities. Food Chem., v.128, n.1, p.152-157, 2011.

KATIYAR, S.K.; AFAQ, F.; AZIZUDDIN, K.; MUKHTAR, H. Inhibition of UVB-Induced Oxidative StressMediated Phosphorylation of Mitogen-Activated Protein Kinase Signaling Pathways in Cultured Human Epidermal Keratinocytes by Green Tea Polyphenol (-)-Epigallocatechin-3-gallate. Toxicol. Appl. Pharmacol., v.176, n.2, p.110-117, 2001.

KATO, A.; FUJISHIGE, T.; MATSUDOMI, N.; KOBAYASHI, K. Determination of emulsifying properties of some proteins by conductivity measurements. J. Food Sci., v.50, n.1, p.56-58, 1985.

KULlaVANIJAYA, P.; LIM, H.W. Photoprotection. J. Am. Acad. Dermatol., v.52, n.6, p.937-958, 2005.
KUSKOSKI, E.M.; ASUERO, A.G.; MORALES M.T.; FETT, R. Frutos tropicais silvestres e polpas de frutas congeladas: atividade antioxidante, polifenóis e antocianinas. Ciênc. Rural, v.36, n.4, p.1283-1287, 2006.

LEE, C.H.; MOTURI, V.; LEE, Y. Thixotropic property in pharmaceutical formulations. J. Control. Release, v.136, n.2, p.88-98, 2009.

LEONARDI, G.R.; BERALDI, P.; FREITAS, P.C.D.; CAMPOS, P.M.M. Produto de uso tópico com Aloe vera. Cosmet. Toiletries, v.12, n.5, p.44-53, 2000.

LIMA, C.G.; VILELA, A.F.G.; SILVA, A.A.S.; PIANNOVSKI, A.R.; SILVA, K.K.; CARVALHO, V.F.M.; DE MUSIS, C.R.; MACHADO, S.R.P.; FERRARI, M. Desenvolvimento e avaliação da estabilidade física de emulsões $\mathrm{O} / \mathrm{A}$ contendo óleo de babaçu (Orbignya oleifera). Rev. Bras. Farm., v.89, n.3, p.239-245, 2008.

LOCHEAD, R.Y.; HEMKER, W.J.; CASTANEDA, J.Y.; GARLEN, D. Novel cosmetic emulsions. Cosmet. Toiletries, v.101, n.11, p.125-138, 1986.

LOHÉZIC-LE DÉVÉHAT, F.; LEGOUIN, B.; COUTEAU, C.; BOUSTIE, J.; COIFFARD, L. Lichenic extracts and metabolites as UV filters. J. Photochem. Photobiol. B, v.120, p.17-28, 2013.

LOPES, T.J.; XAVIER, M.F.; QUADRI, M.G.N.; QUADRI, M.B. Antocianinas: uma breve revisão das características estruturais e da estabilidade. Rev. Bras. Agrociênc., v.13, n.3, p.291-297, 2007.

LUBRIZOL. Carbopol ultrez 10 polymer for personal care applications. Cleveland: Lubrizol Advanced Materials Inc., 2007. 4 p. (Technical Data Sheet, 225).

MANSUR, M.C.P.P.R.; LEITÃO, S.G.; LIMA, L.M.T.R.; RICCI-JÚNIOR, E.; DE SOUZA, G.R.; BARBI, N.S.; MARTINS, T.S.; DELLAMORA-ORTIZ, G.M.; LEO, R.R.T.; VIEIRA, R.C.; LEITÃO, G.G.; DOS SANTOS, E.P. Evaluation of the antioxidant and phototoxic potentials of Bauhinia microstachya var. massambabensis Vaz leaf extracts. Lat. Am. J. Pharm., v.31, n.2, p.200-206, 2012.

MASMOUDI, H.; DRÉAU, Y.L.; PICCERELLE, P.; KISTER, $\mathrm{J}$. The evaluation of cosmetic and pharmaceutical emulsions aging process using classical techniques and a new method: FTIR. Int. J. Pharm., v.289, n.1-2, p.117-131, 2005. 
MENDONÇA, C.C.; SILVA, I.C.L.; RODRIGUES, K.A.; CAMPOS, M.A.L.; MEDEIROS, M.C.M.; CASTELI, V.C.; FERRARI, M.; MUSIS, C.R.; MACHADO, S.R.P. Emulsões $\mathrm{O} / \mathrm{A}$ contendo Cetoconazol 2,0\%: avaliação da estabilidade acelerada e estudos de liberação in vitro. Rev. Ciênc. Farm. Básica Apl., v.30, n.1, p.35-46, 2009.

PACHECO-PALENCIA, L.A.; DUNCAN, C.E.; TALCOTT, S.T. Phytochemical composition and thermal satbility of two commercial açaí species, Euterpe oleracea and Euterpe precatoria. Food Chem., v.115, n.4, p.1199-1205, 2009.

PEARCE, K.N.; KINSELLA, J.E. Emulsifying properties of proteins: evaluation of a turbidimetric technique. J. Agric. Food Chem., v.26, n.3, p.716-723, 1978.

PIANOVSKI, A.R.; VILELA, A.F.G.; SILVA, A.A.S.; LIMA, C.G.; SILVA, K.K.; CARVALHO, V.F.M.; MUSIS, C.R.; MACHADO, S.R.P.; FERRARI, M. Desenvolvimento e avaliação da estabilidade de emulsões múltiplas $\mathrm{O} / \mathrm{A} / \mathrm{O}$ com óleo de pequi (Caryocar brasiliense). Rev. Bras. Farm., v.89, n.2, p.155-159, 2008.

POYATO, C.; NAVARRO-BLASCO, I.; CALVO, M.I.; CAVERO, R.Y.; ASTIASARÁN, I.; ANSORENA, D. Oxidative stability of $\mathrm{O} / \mathrm{W}$ and $\mathrm{W} / \mathrm{O} / \mathrm{W}$ emulsions: Effect of lipid composition and antioxidant polarity. Food Res. Int., v.51, n.1, p.132-140, 2013.

RAMOS, M.F.S.; SANTOS, E.P.; BIZARRI, C.H.B.; MATTOS, H.A.; PADILHA, M.R.S.; DUARTE, H.M. Preliminary studies towards utilization of various plant extracts as antisolar agents. Int. J. Cosmetic Sci., v.18, n.3, p.87-101, 1996.

RANCAN, F.; ROSAN, S.; BOEHM, K.; FERNANDEZ, E.; HIDALGO, M.E.; QUIHOT, W.; RUBIO, C.; BOEHM, F.; PIAZENA, H.; OLTMANNS, U. Protection against UVB irradiation by natural filters extracted from lichens. J. Photochem. Photobiol. B, v.68, n.2-3, p.133-139, 2002.

SAMBANDAN, D.R.; RATNER, D. Sunscreens: an overview and update. J. Am. Acad. Dermatol., v.64, n.4, p.748-758, 2011.
SCHAUSS, A.G.; WU, X.; PRIOR, R.L.; OU, B.; HUANG, H.; OWENS, J.; AGARWAL, A.; JENSEN, G.S.; HART, A.N.; SHANBROM, E. Antioxidant capacity and other bioactivities of the freeze-dried amazonian palm berry, Euterpe oleraceae Mart. (Acai). J. Agric. Food Chem., v.54, n.22, p.8604-8610, 2006.

SILVA, A.A.S.; ROPKE, C.D.; ALMEIDA, R.L.; MIRANDA, D.V.; KERA, C.Z.; RIVELLI, D.P.; SAWADA, T.C.H.; BARROS, S.B.M. Chemical stability and SPF determination of Pothomorphe umbellata extract gel and photostability of 4-nerolidylcathecol. Int. J. Pharm., v.303, n.1-2, p.125-131, 2005.

SOUSA, C.M.D.M.; SILVA, H.R.; VIEIRA-JR., G.M.; AYRES, M.C.C.; COSTA, C.L.S.; ARAÚJO, D.S.; CAVALCANTE, L.C.D.; BARROS, E.D.S.; ARAÚJO, P.B.M.; BRANDÃO, M.S.; CHAVES, M.H. Fenóis totais e atividade antioxidante de cinco plantas medicinais. Quím. Nova, v.30, n.2, p.351$355,2007$.

SOUZA, T.M.; SANTOS, L.E.; MOREIRA, R.R.D.; RANGEL, V.L.B.I. Avaliação da atividade fotoprotetora de Achillea millefolium L. (Asteraceae). Rev. Bras. Farmacogn., v.15, n.1, p.36-38, 2005.

TADROS, T. Application of rheology for assessment and prediction of the long-term physical stability of emulsions. Adv. Colloid Interface Sci., v.108-109, p.227-258, 2004.

TCHOLAKOVA, S.; DENKOV, N.D.; IVANOV, I.B.; CAMPBELL, B. Coalescence stability of emulsions containing globular Milk proteins. Adv. Colloid Interface Sci., v.123-126, p.259-293, 2006.

VELASCO, M.V.R.; BALOGH, T.S.; PEDRIALI, C.A.; SARRUF, F.D.; PINTO, C.A.S.O.; KANEKO, T.M.; BABY, A.R. Associação da rutina com $p$-metoxicinamato de octila e benzofenona-3: avaliação in vitro da eficácia fotoprotetora por espectrofotometria de refletância. Lat. Am. J. Pharm., v.27, n.1, p.23-27, 2008a.

VELASCO, M.V.R.; SARRUF, F.D.; SALGADO-SANTOS, I.M.N.; HAROUTIOUNIAN-FILHO, C.A.; KANEKO, T.M.; BABY, A.R. Broad spectrum bioactive sunscreens. Int. J. Pharm., v.363, n.1-2, p.50-57, 2008 b. 
VIOLANTE, I.M.P.; SOUZA, I.M.; VENTURINI, C.L.; RAMALHO, A.F.S.; SANTOS, R.A.N.; FERRARI, M. Avaliação in vitro da atividade fotoprotetora de extratos vegetais do cerrado de Mato Grosso. Rev. Bras. Farmacogn., v.19, n.2, p.452-457, 2009.

WANG, S.Q.; OSTERWALDER, U.; JUNG, K. Ex vivo evaluation of radical sun protection factor in popular sunscreens with antioxidants. J. Am. Acad. Dermatol., v.65, n.3, p.525-530, 2011.
ZHANG, K-M.; YU, H-J.; ZHOU, Y-H.; YU, J-Q., XIA, $\mathrm{X}-\mathrm{J}$. Photoprotective roles of anthocyanins in Begonia semperflorens. Plant Sci., v.179, n.3, p.202-208, 2010.

Received for publication on $11^{\text {th }}$ November 2013 Accepted for publication on $13^{\text {th }}$ March 2014 